\title{
HUBUNGAN MOTIVASI BELAJAR TERHADAP PRESTASI AKADEMIK PADA MAHASISWA YANG MENJALANI PEMBELAJARAN DARING SELAMA PANDEMI COVID-19
}

\author{
Muhammad Taufik Daniel Hasibuan, Hendry Kiswanto Mendrofa, Harsudianto Silaen, \\ Yusrial Tarihoran \\ Program Studi Ilmu Keperawatan, STIKes Murni Teguh \\ E-mail : aniel.jibril@gmail.com; hendrykiswanto155@gmail.com; \\ antosilaen4@gmail.com; yusrialtarihoran@gmail.com
}

\begin{abstract}
Education is currently experiencing challenges as a result of the Covid-19 pandemic, so the government has issued a study from home policy using online methods to reduce the spread of the virus. During the pandemic there was a change in the learning environment and this required adaptation and had an impact on students. The learning environment has an influence on learning motivation and ultimately will affect academic achievement. This study aims to look at the relationship between learning motivation and academic achievement in students who undergo online learning during the Covid-19 pandemic. This type of research is quantitative using a cross sectional design and the sample used in this study amounted to 85 people, and simple random sampling was used as a sampling technique for the population. Collecting research data using a questionnaire distributed via google form to facilitate access during a pandemic, and data analysis used using the Spearman test. From the results of the correlation test, it was found that there was no significant relationship between learning motivation and academic achievement in students who underwent online learning during the Covid-19 pandemic, $p=0.288$. Academic achievement cannot be influenced by motivation alone, but from several supporting factors behind it. Efforts should be made to improve the quality of learning during the Covid-19 pandemic.
\end{abstract}

Keywords : Learning Motivation, Academic Achievement, Online Learning, Covid-19

\begin{abstract}
Abstrak
Pendidikan saat ini tengah mengalami tantangan sebagai dampak pandemi Covid-19, sehingga pemerintah mengeluarkan kebijakan belajar dari rumah dengan menggunakan metode daring untuk menekan laju penyebaran virus. Pada masa pandemi terjadi perubahan lingkungan belajar dan hal ini membutuhkan adaptasi serta menimbulkan dampak bagi mahasiswa. Lingkungan belajar memiliki pengaruh terhadap motivasi belajar dan akhirnya akan mempengaruhi terhadap prestasi akademik. Penelitian ini bertujuan untuk melihat hubungan motivasi belajar terhadap prestasi akademik pada mahasiswa yang menjalani pembelajaran daring selama pandemi covid-19. Jenis penelitan ini kuantitatif dengan menggunakan cross sectional design dan sampel yang dipakai dalam penelitian ini berjumlah 85 orang, serta simple random sampling dipakai sebagai teknik pengambilan sampel pada populasi. Pengumpulan data penelitian menggunakan kuesioner yang dibagikan melalui google form untuk mempermudah akses selama pandemi, serta analisa data yang digunakan memakai uji Spearman. Dari hasil uji korelasi didapatkan bahwa tidak ada hubungan yang signifikan antara motivasi belajar terhadap prestasi akademik pada mahasiswa yang menjalani pembelajaran daring selama pandemi covid-19, $\mathrm{p}=0.288$. Prestasi akademik tidak dapat dipengaruhi oleh motivasi saja, melainkan dari beberapa faktor pendukung yang melatar belakanginya. Perlu dilakukan upaya terhadap peningkatan kualitas pembelajaran selama pandemi Covid-19.
\end{abstract}

Kata Kunci : Motivasi Belajar, Prestasi Akademik, Pembelajaran Daring, Covid-19 


\section{PENDAHULUAN}

Pada tahun 2020, Bangsa Indonesia dan bangsa di negara-negara lain sedang dilanda pandemi Covid-19. Kondisi ini memberikan tantangan dan peluang untuk kita bangkit serta keluar dari rutinitas yang ada. Berdasarkan kebijakan pemerintah tentang bekerja, belajar, dan ibadah dari rumah menjadikan momentum yang baik untuk menciptakan kreativitas dan memanfaatkan teknologi sesuai dengan eranya. Berdasarkan Surat Edaran Nomor 4 Tahun 2020 tentang Pelaksanaan Kebijakan Pendidikan dalam masa pandemi Covid-19, Kemendikbud menghimbau agar semua lembaga pendidikan tidak melakukan proses belajar mengajar secara langsung atau tatap muka, melainkan harus dilakukan secara tidak langsung atau jarak jauh (daring) (Kemendikbud, 2020).

Pembelajaran merupakan proses yang sangat penting dari pendidikan. Pendidikan merupakan sebuah proses pembelajaran dari pengetahuan, keterampilan, sikap dan perilaku sosial, dimana dalam menjalani proses tersebut harus melewati tahapan yang telah dibuat untuk tercapainya sebuah tujuan (Fenti, 2010). Pendidikan saat ini tengah mengalami tantangan sebagai dampak mewabahnya virus Covid-19, sehingga pemerintah harus bekerja sama untuk menekan laju penyebaran virus Covid-19 dengan mengeluarkan kebijakan agar seluruh warga masyarakat melakukan social distancing atau menjaga jarak. Salah satu instruksi pemerintah tentang kegiatan yang dilakukan di rumah adalah kegiatan belajar. Belajar tidak boleh berhenti. Kegiatan belajar mengajar dipindahkan di rumah, tetapi harus dikendalikan oleh guru atau dosen dan orang tua, dengan menggunakan pembelajaran jarak jauh. (Anissa, Zaharah, \& Galia,2020).

Penggunaan teknologi dalam dunia pendidikan telah menjadi isu yang sagat penting dan sering dibicarakan dalam berbagai kegiatan (Orgaz et al., 2018; Traxler, 2018). Perkembangan teknologi menjadi sebuah potensi dalam berbagai bidang khususnya dalam bidang pendidikan sehingga harus direspon secara positif dan adaptif dalam menjawab tantangan abad 21 yang penuh kompleksitas (Aziz, 2018; Gamar et al., 2018). Keberadaan teknologi bagi dunia pendidikan merupakan sarana yang dapat dipakai sebagai media penyampaian program pembelajaran baik secara searah maupun secara interaktif (Husaini, 2014). Menurut Denker (2013) proses belajar sekarang tidak lagi dibatasi oleh ruang kelas, selain itu penggunaan teknologi telah memungkinkan munculnya pembelajaran jarak jauh dan mendorong inovasi yang lebih besar dalam menciptakan metode pengajaran di dalam dan di luar kelas (Almeida \& Simoes, 2019).

Pembelajaran daring merupakan sebuah inovasi pendidikan yang melibatkan unsur teknologi informasi dalam pembelajaran. Menurut Mustofa et al (2019) bahwa Pembelajaran daring merupakan sistem pendidikan jarak jauh dengan sekumpulan metoda pengajaran dimana terdapat aktivitas pengajaran yang dilaksanakan secara terpisah dari aktivitas belajar. Menurut Alessandro (2018) pembelajaran daring diselenggarakan melalui jejaring internet dan web 2.0, artinya bahwa penggunaan pembelajaran daring melibatkan unsur teknologi sebagai sarana dan jaringan internet sebagai sistem. Pembelajaran daring sudah mulai dilakukan dalam konteks perguruan tinggi, terbukti dari beberapa penelitian yang menjelaskan hal tersebut (Crews \& Parker, 2017; Mather \& Sarkans, 2018). Pembelajaran daring memberikan manfaat dalam membantu menyediakan akses belajar bagi semua orang, sehingga menghapus hambatan secara fisik sebagai faktor untuk belajar dalam ruang lingkup kelas (Riaz, 2018). Meskipun demikian, menurut Pilkington (2018) tidak bisa dipungkiri bahwa tidak semua pembelajaran dapat dipindahkan ke dalam lingkungan pembelajaran secara online.

Motivasi belajar berpengaruh dalam keberhasilan pembelajaran. Adanya motivasi belajar yang tinggi membuat mahasiswa belajar dengan tekun, yang pada akhirnya akan terwujud dalam prestasi akademik. 
Menurut Emda (2018) proses pembelajaran akan mencapai keberhasilan jika siswa memiliki motivasi belajar yang baik. Oleh karena itu, motivasi belajar sangat penting dimiliki oleh setiap mahasiswa, baik motivasi intrinsik maupun ekstrinsik. Perubahan proses pembelajaran di tengah pandemi tentu menjadi suatu tantangan tersendiri bagi seluruh lembaga pendidikan. Damanik (2019) mengungkapkan dalam hasil penelitiannya, bahwa lingkungan belajar memiliki pengaruh yang signifikan terhadap motivasi belajar. Pada masa pandemi terjadi perubahan lingkungan belajar, yang tadinya berada disekolah bersama guru dan temanteman menjadi di rumah didampingi orang tua. Hal ini tentu akan membutuhkan adaptasi serta menimbulkan dampak bagi peserta didik. Lingkungan belajar harus diciptakan sepositif mungkin setara dengan lingkungan sekolah, agar motivasi belajar siswa dapat tumbuh. Menurut Fenti (2010) tuntutan pendidikan yang harus dijalani akan menjadi faktor pemicu timbulnya stres belajar pada mahasiswa. Dari hasil penelitian korelasi yang dilakukan Hasibuan (2019) bahwa didapatkan hubungan yang signifikan antara stres belajar dengan motivasi belajar, dengan nilai sig. 0.000. Saat seseorang mengalami ketidaksesuaian antara tuntutan dan kemampuan didalam mengatasinya, hal ini dapat menimbulkan masalah seperti stres, dan stres belajar merupakan masalah yang sering terjadi dilingkungan pendidikan. Sehubungan hal itu, pihak sekolah harus menciptakan pembelajaran yang berkualitas sehingga tercipta motivasi belajar mahasiswa yang tinggi sehingga dapat meningkatkan prestasi belajar dari peserta didik (Hasanah, 2015).

\section{METODE PENELITIAN}

Jenis penelitian ini kuantitatif dengan menggunakan cross sectional design. Teknik pengambilan sampel menggunakan simple random sampling dengan jumlah sampel sebanyak 85 orang yang berstatus sebagai mahasiswa aktif. Penelitian ini telah dilakukan di STIKes Murni Teguh pada bulan Agustus sampai dengan Oktober 2020.
Pengumpulan data penelitian menggunakan kuesioner yang berisi 40 item pernyataan tentang motivasi belajar dan 1 item penilaian prestasi akademik yang dilihat dari indeks prestasi kumulatif (IPK) semester genap T.A 2019/2020, yang dibagikan melalui google form untuk mempermudah akses selama masa pandemi.

Tahapan dalam proses penelitian, yaitu 1) Tahap pertama : peneliti meminta izin kepada calon responden, 2) Tahap kedua : peneliti memberikan kuisioner dari google form dan mengukur tingkat motivasi belajar dan prestasi akademik mahasiswa selama menjalani perkuliahan di masa pandemi, 3) Tahap ketiga : peneliti melakukan analisis data univariat dan bivariat dengan menghubungkan antara variabel independent dan variabel dependent dengan memakai sistem komputerisasi uji Spearman.

\section{HASIL PENELITIAN \\ Karakteristik Responden}

Data demografi menunjukkan bahwa mayoritas responden berada pada usia 17-20 tahun sebanyak $47(55.3 \%)$, jenis kelamin perempuan sebanyak 78 (91.8\%), dan berada pada tingkat 3 sebanyak 25 (29.4\%). Penjelasan terlihat pada table 1.

Tabel 1. Distribusi Frekuensi Data Demografi ( $\mathbf{N}=85)$

\begin{tabular}{|c|c|c|}
\hline $\begin{array}{l}\text { Karakteristik } \\
\text { Responden }\end{array}$ & $\frac{\text { Frekuensi }}{\mathrm{n}}$ & $\frac{\text { Persentase }}{\%}$ \\
\hline \multicolumn{3}{|l|}{ Usia } \\
\hline $17-20$ & 47 & 55.3 \\
\hline $21-24$ & 38 & 44.7 \\
\hline Total & 85 & 100 \\
\hline \multicolumn{3}{|l|}{ Jenis Kelamin } \\
\hline Laki-Laki & 7 & 8.2 \\
\hline Perempuan & 78 & 91.8 \\
\hline Total & 85 & 100 \\
\hline \multicolumn{3}{|c|}{ Tingkat Akademik } \\
\hline Satu & 15 & 17.6 \\
\hline Dua & 21 & 24.7 \\
\hline Tiga & 25 & 29.4 \\
\hline Empat & 24 & 28.2 \\
\hline Total & 85 & 100 \\
\hline
\end{tabular}




\section{Motivasi Belajar Pada Mahasiswa Yang Menjalani Pembelajaran Daring}

Dari hasil penelitian tentang motivasi belajar pada mahasiswa yang menjalani pembelajaran daring didapatkan nilai distribusi frekuensi yaitu motivasi belajar sangat tinggi sebanyak 38 (44.7\%), motivasi belajar tinggi sebanyak 41 (48.2\%), dan motivasi belajar sedang sebanyak 6 (7.1\%). Penjelasan terlihat pada tabel 2 .

Tabel 2. Distribusi Frekuensi Pada Motivasi Belajar Mahasiswa Yang Menjalani Pembelajaran Daring ( $\mathbf{N}=\mathbf{8 5})$

\begin{tabular}{lcc}
\hline \multirow{2}{*}{ Motivasi Belajar } & Frekuensi & Persentase \\
\cline { 2 - 3 } & $\mathbf{n}$ & $\mathbf{\%}$ \\
\hline Sangat Tinggi & 38 & 44.7 \\
\hline Tinggi & 41 & 48.2 \\
\hline Sedang & 6 & 7.1 \\
\hline Rendah & - & - \\
\hline \multicolumn{1}{c}{ Total } & $\mathbf{8 5}$ & $\mathbf{1 0 0}$ \\
\hline \multicolumn{2}{c}{}
\end{tabular}

\section{Prestasi Akademik Pada Mahasiswa Yang Menjalani Pembelajaran Daring}

Dari hasil penelitian tentang prestasi akademik pada mahasiswa yang menjalani pembelajaran daring didapatkan nilai distribusi frekuensi yaitu dengan predikat pujian sebanyak 25 (29.4\%), sangat memuaskan sebanyak $37 \quad(43.5 \%)$, memuaskan sebanyak 18 (21.2\%), dan lulus sebanyak 5 (5.9\%). Penjelasan terlihat pada tabel 3.

Tabel 3. Distribusi Frekuensi Pada Prestasi Akademik Mahasiswa Yang Menjalani Pembelajaran Daring ( $\mathrm{N}=85$ )

\begin{tabular}{lcc}
\hline \multirow{2}{*}{ Prestasi Akademik } & Frekuensi & Persentase \\
\cline { 2 - 3 } & $\mathbf{n}$ & $\mathbf{\%}$ \\
\hline Pujian & 25 & 29.4 \\
\hline Sangat Memuaskan & 37 & 43.5 \\
\hline Memuaskan & 18 & 21.2 \\
\hline Lulus & 5 & 5.9 \\
\hline \multicolumn{1}{c}{ Total } & $\mathbf{8 5}$ & $\mathbf{1 0 0}$ \\
\hline
\end{tabular}

Hubungan Motivasi Belajar Terhadap Prestasi Akademik Pada Mahasiswa Yang Menjalani Pembelajaran Daring Selama Pandemi Covid-19

Dari hasil penelitian didapatkan tidak ada hubungan antara motivasi belajar dengan prestasi akademik pada mahasiswa yang menjalani pembelajaran daring selama pandemi Covid-19, dengan nilai Sig. (2tailed) sebesar 0.288 dan nilai Correlation Coefficient sebesar 0.116. Penjelasan terlihat pada tabel 4.

Tabel 4. Uji Spearman Hubungan Motivasi Belajar Terhadap Prestasi Akademik Pada Mahasiswa Yang Menjalani Pembelajaran Daring Selama Pandemi Covid-19 (N=85)

\begin{tabular}{lcc}
\hline \multicolumn{1}{c}{ Spearman } & $\begin{array}{c}\text { Correlation } \\
\text { Coefficient }\end{array}$ & $\begin{array}{c}\text { Sig. } \\
\text { (2-tailed) }\end{array}$ \\
\cline { 1 - 1 } Stres Belajar & 0.116 & 0.288 \\
\cline { 1 - 1 } Motivasi belajar & & \\
\hline
\end{tabular}

\section{PEMBAHASAN}

Dari hasil penelitian didapatkan bahwa tidak ada hubungan antara motivasi belajar dengan prestasi akademik pada mahasiswa yang menjalani pembelajaran daring selama pandemi Covid-19, dengan nilai sig. 0.288. Prestasi belajar tidak dapat dipengaruhi oleh motivasi saja, melainkan dari beberapa faktor pendukung yang melatar belakanginya. Menurut Riyani (2015) faktorfaktor yang mempengaruhi prestasi belajar adalah : 1) Faktor dari dalam diri individu yang terdiri dari faktor fisiologis. Faktor fisiologis adalah kondisi jasmani dan panca indera. Sedangkan faktor psikologis yaitu bakat, minat, kecerdasan, motivasi dan kemampuan kognitif. 2) Faktor dari luar individu, terdiri dari faktor lingkungan dan faktor instrumental. Faktor lingkungan yaitu sosial dan alam. Sedangkan faktor instrumental yaitu kurikulum, bahan, guru, sarana, administrasi, dan manajemen.

Dari hasil penelitian tentang motivasi belajar pada mahasiswa yang menjalani pembelajaran daring selama pandemi Covid19 , didapatkan nilai distribusi frekuensi yaitu motivasi belajar sangat tinggi sebanyak 38 (44.7\%), motivasi belajar tinggi sebanyak 41 (48.2\%), dan motivasi belajar sedang sebanyak $6(7.1 \%)$. Meskipun pembelajaran tidak dilakukan secara langsung, mahasiswa tetap memiliki motivasi didalam proses belajar. Menurut Sardiman (2014) motivasi 
tumbuh didalam diri individu. Motivasi berfungsi sebagai penggerak didalam kegiatan belajar, menjamin kelangsungan dari kegiatan belajar, dan memberikan arah pada kegiatan belajar, sehingga tujuan yang dikehendaki oleh seseorang dapat tercapai. Menurut Wlodkowski (2004) motivasi belajar sangat penting didalam pengembangan diri, karena pengembangan diri adalah belajar.

Dari hasil penelitian tentang prestasi akademik pada mahasiswa yang menjalani pembelajaran daring selama pandemi Covid19, didapatkan nilai distribusi frekuensi yaitu dengan predikat pujian sebanyak 25 (29.4\%), sangat memuaskan sebanyak $37(43.5 \%)$, memuaskan sebanyak 18 (21.2\%), dan lulus sebanyak 5 (5.9\%). Prestasi akademik selama masa pandemi tidak hanya dipengaruhi oleh motivasi belajar saja, melainkan bisa dipengaruhi oleh beberapa faktor seperti media belajar, proses belajar, suasana belajar, dukungan orang tua dan lain sebagainya. Meskipun demikian, upaya yang dilakukan oleh institusi pendidikan sebagai ujung tombak dalam menjalankan proses pendidikan sudah sangat maksimal. Covid-19 sebagai bencana non alam merupakan masalah baru bagi dunia pendidikan seperti ditetapkannya aturan belajar melalui daring. Hal ini dilakukan oleh pemerintah dengan harapan virus tidak menyebar lebih luas dan upaya penyembuhan dapat berjalan maksimal dan sesuai dengan harapan bersama.

\section{KESIMPULAN}

Kesimpulan hasil penelitian ini adalah :

1. Tidak ada hubungan yang signifikan antara motivasi belajar dengan prestasi akademik pada mahasiswa yang menjalani pembelajaran daring selama pandemi Covid-19

2. Mayoritas usia responden berada pada usia 17-20 tahun sebanyak 47 (55.3\%), jenis kelamin perempuan sebanyak 78 (91.8\%), dan berada pada tingkat 3 sebanyak 25 (29.4\%).

\section{SARAN}

1. Bagi Mahasiswa

Hasil penelitian ini diharapkan menjadi masukan kepada mahasiswa untuk tetap mempertahankan dan meningkatkan motivasi belajar meskipun dalam masa pandemi covid-19

2. Bagi pendidikan

Hasil penelitian ini diharapkan menjadi informasi tambahan bagi instansi pendidikan

3. Bagi penelitian selanjutnya

Diharapkan untuk mengkaji faktor-faktor yang mempengaruhi prestasi akademik pada mahasiswa yang menjalani pembelajaran daring selama pandemi Covid-19, disamping itu juga perlu menambahkan variabel lain dalam memperkaya bahasan penelitian.

\section{REFERENSI}

Alessandro, B. (2018). Digital skills and competence, and digital and online learning. Turin: European Training Foundation.

Almeida, F., \& Simoes, J. (2019). The role of serious games, gamification and industry 4.0 tools in the education 4.0 paradigm. Contemporary Educational Technology, 10(2), 120136. https://doi.org/10.30935/cet.554 469

Anissa, W., Zaharah., Galia. (2020). Impact of corona virus outbreak towards teaching and learning activities in indonesia. Jurnal Sosial dan Budaya Syar'i, 07, no. 03 (t.t.): 269-82. https://doi.org/10.15408/sjsbs.v7i3.1 5104.

Aziz, H, A. (2018). Education 4.0 made simple: ideas for teaching. International Journal of Education and Literacy Studies, 6(3), 92-98. https://doi.org/10.7575/aiac.ijels.v.6 n.3p.92.

Crews, J., \& Parker, J. (2017). The cambodian experience: exploring university students' perspectives for online learning. Issues in 
Educational Research, 27(4), 697719.

Damanik, B. E. (2019). Pengaruh fasilitas dan lingkungan belajar terhadap motivasi belajar. Publikasi Pendidikan, $9(1), \quad 46$. https://doi.org/10.26858/publikan.v9i 1.7739

Denker, K. J. (2013). Student response systems and facilitating the large lecture basic communication course: assessing engagement and learning. Communication Teacher, 27(1), 50 69. https://doi.org/10.1080/174046 22.2012.730622.

Emda, A. (2018). Kedudukan motivasi belajar siswa dalam pembelajaran. Lantanida Journal, 5(2), 172. https://doi.org/10.22373/lj.v5i2.2838

Fenti, H. (2010). Bimbingan konseling. Jakarta : Rajagrafindo.

Gamar, M. M., Al Faruq, M. S., \& Lina, L. (2018). Challenging the Indonesian primary education in industrial revolution 4.0 era. 3rd International Conference on Education Management and Administration (CoEMA 2018), 269, 46-48. https://doi.org/10.2991/coema18.2018.12.

Hasanah, U. (2015). Hubungan lingkungan sekolah dan motivasi belajar dengan hasil belajar IPS siswa kelas VIII di Mtsn Amuntai. Jurnal Socius, 4(2). https://doi.org/10.20527/jurnalsocius .v4i2.3314

Hasibuan, M.T.D. (2019). Hubungan stres belajar dengan motivasi belajar pada mahasiswa yang menjalani pendidikan di sekolah tinggi ilmu kesehatan murni teguh. Indonesian Trust Health Journal, vol.2, no.1, Agustus 2019. ISSN p: 2620-5564, e: 2655-1292.

Husaini, M. (2014). Pemanfaatan teknologi informasi dalam bidang pendidikan (education). Jurnal Mikrotik, 2(1), 15.

Kemendikbud. (2020). Panduan pengenalan keghidupan kampus bagi mahasiswa baru (PKKMB) tahun 2020. Direktorat Jenderal Pendidikan Tinggi

Kemendikbud. (2020). Surat edaran mendikbud no 4 tahun 2020 tentang pelaksanaan kebijakan pendidikan dalam masa darurat penyebaran corona virus disease (COVID-19). Pusdiklat Pegawai Kementerian Pendidikan dan Kebudayaan.

Mather, M., \& Sarkans, A. (2018). Student perceptions of online and face-toface learning. International Journal of Curriculum and Instruction, 10(2), 61-76.

Mustofa, M. I., Chodzirin, M., Sayekti, L., \& Fauzan, R. (2019). Formulasi model perkuliahan daring sebagai upaya menekan disparitas kualitas perguruan tinggi. Walisongo Journal of Information Technology, 1(2), 151. https://doi.org/10.21580/ wjit.2019.1.2.4067.

Orgaz, F., Moral, S., \& Domínguez, C. (2018). Student's attitude and perception with the use of technology in the university. Journal of Educational Psychology Propositos Y Representaciones, 6(2), 277-299. https://doi.org/http://dx. doi.org/10.20511/pyr2018.v6n2.230.

Pilkington, O. A. (2018). Active learning for an online composition classroom: blogging as an enhancement of online curriculum. Journal of Educational Technology Systems, 47(2), 1-14. https://doi.org/10.1177/ 0047239518788278.

Riaz, A. (2018). Effects of online education on encoding and decoding process of students and teachers. International Conference E-Learning, 42-48. https://files.eric.ed.gov/fulltext/ED59 0288.pdf.

Riyani, Y. (2015). Faktor-faktor yang mempengaruhi prestasi belajar mahasiswa (studi pada mahasiswa Jurusan Akuntansi Politeknik Negeri Pontianak). 
Cetak ISSN : 2620-5564

Online ISSN : 2655-1292

Sardiman, A.M. (2014). Interaksi dan motivasi belajar. Jakarta : PT Raja Grafindo Persada.

Traxler, J. (2018). Distance learningpredictions and possibilities. Education Sciences, 8(1), 1-13. https://doi.org/10.3390/educsci80100 35.

Wlodkowski, R, J. (2004). Hasrat untuk belajar. Yogyakata : Pustaka Pelajar 